\title{
Exploring adult learners' self-directedness in relation to their employability attributes in open distance learning
}

\author{
Jo-Anne Botha*a ${ }^{\mathrm{a}}$, Melinde Coetzee ${ }^{\mathrm{b}}, \&$ Mariette Coetzee ${ }^{\mathrm{a}}$ \\ ${ }^{a}$ Department of Human Resource Management, University of South Africa \\ ${ }^{b}$ Department of Industrial and Organisational Psychology, University of South Africa \\ *E-mail: bothaj1@unisa.ac.za
}

This study investigated the relationship between adult learners' self-directedness and their perceptions of their employability attributes. A stratified proportional random sample $(N=$ 1 102) was taken of undergraduate adult learners at a South African open distance learning (ODL) higher education institution. The sample was predominantly represented by early-career black and female participants who were employed in industry and pursuing further studies in the economic and management sciences field. The results showed that learners who had a strong sense of self-directedness and especially a success orientation toward studying in an ODL environment had more confidence in their employability attributes and felt especially positive about their proactivity, career self-management and career resilience.

Keywords: adult learner, open distance learning, employability attributes, self-directedness, success orientation, proactivity, career self-management 
The employability of graduates from tertiary education has been a much-explored theme in the literature the past few years and is of special significance in the South African environment where the unemployment rate of young graduates is growing yearly (Coetzee \& Botha, 2013; Coetzee \& Beukes, 2010; Morrison, 2013; Nel \& Neal-Shuttle, 2013). The employability of graduate students relates to learners' personal assessment of their capacity to deal with the world of work in the future and the active adaptability they demonstrate to identify and realise career opportunities (Fugate, Kinicki, \& Ashforth, 2004; Van der Heijde \& Van der Heijden, 2006). Life-long and life-wide learning have become imperatives for adult learners in the light of increasing changes in the labour market, uncertain career paths and an evolving knowledge economy (Louw, 2014; Nazar \& Van der Heijden, 2012; Thijssen, Van der Heijden, \& Rocco, 2008). Adult learners therefore often engage in further educational studies in order to enhance their employability (Botha, 2014; Louw, 2014).

The study of adult learners and their employability has also increased in importance with the growth of ODL as a means of furthering one's educational studies (Ladell-Thomas, 2012). ODL presupposes a well-developed sense of learner self-directedness that may be presumed to exist, but has not yet been researched and reported on thoroughly as a concept (Klein-Collins, 2011). Moreover, the topic of adult learners' self-directedness and if and how this affects their employability has not been explored in great depth, specifically in the South African environment (Botha, 2014).

\section{Adult learner self-directedness}

Knowles (1984) was one of the first authors to conceptualise and describe the notion of adult learning, thereby differentiating between the pedagogical approaches expounded by educators as applicable to the learning of children, and the approach to be followed in the learning of adults. Knowles coined the phrase 'andragogy' to identify this approach. Andragogy embraces the notions of self-directedness, readiness for learning, using life experiences in learning, and having the intrinsic motivation for learning (Botha, 2012; 2014).

Self-directed learners are seen to actively participate in their personal learning journeys, from inception to conclusion (Botha, 2014; Knowles, 1984; Lai, Gardner, \& Law, 2013). They 
know their specific learning requirements and personal learning preferences and can self-monitor and reflect productively on their own learning in order to achieve their goals (Knowles, 1984; Lai et al., 2013). Adult self-directed learners are self-motivated and focus on acquiring competence in order to solve specific problems (Knowles, 1984). Since self-directed adult learners manage their own learning, they require a facilitative environment in which to learn optimally (Knowles, 1984).

Models of learner self-directedness that flow from the ground-breaking work by Knowles (1984) include Garrison's (1997) model, which focuses on self-directedness in educational surroundings as opposed to self-directedness in the workplace; Silen and Uhlin's (2008) chaos vs. cosmos model; and Botha's (2014) model, which focuses specifically on adult learners in ODL settings. Garrison's (1997) model of self-directedness in educational settings considers both the observable behaviours and the underlying motivations, beliefs and attitudes that drive adult learners' behaviour. Adult learners' ability and disposition for self-directedness in learning are seen as the glue that links their underlying motives, attitudes and beliefs and study behaviour (Garrison, 1997). The chaos vs. cosmos model (Silen \& Uhlin, 2008) utilises the foundational elements of Garrison's model, with a specific focus on the learners' emotional states when they suddenly face a higher education setting and the concomitant expectations for which they may feel ill prepared (chaos), and 'cosmos' - the methods adult learners employ to fashion order from the perceived confusion (Silen \& Uhlin, 2008). The model hinges on creating equilibrium between the adult learners' need for direction and teamwork and the academic staff's (sometimes incorrect) assumption that higher education students are autonomous and self-directed in their learning (Botha, 2014).

Botha's (2014) model of adult learner self-directedness in ODL settings is of relevance to the present study. The model attempts to integrate the contextual, behavioural and psychological foundations of adult learner self-directedness in order to position learners in ODL environments on a development path of self-directedness (Coetzee \& Botha, 2013). As illustrated in Figure 1, adult learner self-directedness is assumed to comprise four psycho-social behavioural domains. The four facets of the model are interrelated and draw upon psychological (dispositional orientations or attitudes), social (behavioural interactions with the learning context) and 
behavioural (self-directed activities) components of the construct of self-directedness (Botha, 2014). The four facets of Botha's model are as follows:

1) The strategic utilisation of officially provided resources which refers to when, how and for what purpose learners use the official learning resources provided by the university. Adult learners' use of officially provided learning resources may afford early insights into their self-managing learning behaviours, such as self-assessing study guide activities and using feedback on assignments to interrogate learning actions (Botha, 2014; Coetzee \& Botha, 2013).

2) Engaged academic activity describes the deliberate, decisive learning activities of adult learners in order to develop competence and progress in their studies (Botha, 2014; Coetzee \& Botha, 2013). Engaged academic activity indicates whether and how adult students become actively involved in study by using the learning material - how much time is spent per module in order to ensure study success. Engaged academic activity provides a glimpse into the academic maturity of the adult students as manifested in their actual study behaviour and is the behavioural mirror image of strategic utilisation of officially provided resources (Botha, 2014; Coetzee \& Botha, 2013).

3) Success orientation for $O D L$ describes the self-reported cognitive processes of adult learners around their self-efficacy beliefs as regards tertiary studies (Botha, 2014; Coetzee \& Botha, 2013). Success orientation for ODL is seen as a psychological toolbox that adult learners possess and that facilitates their success (Botha, 2014; Coetzee \& Botha, 2013).

4) Academically motivated behaviour describes adult learners' self-reported behaviour regarding the locus of their motivation for learning and certain psychological prerequisites for successful learning in the ODL setting (Botha, 2014; Coetzee \& Botha, 2013). Academically motivated behaviour is seen as the behavioural mirror-image of success orientation for ODL.

<Insert figure 1 approximately here>

Self-directed learning, self-learning skills and autonomy appear to be important in dealing successfully with the challenging nature of an ODL experience (Coetzee, 2014; De Ture, 
2004; Faber, López, \& Prescher, 2012). Self-directedness has been associated with lifepreparedness, which includes the cultivation and nurturing of attributes such as agency, resilience, agility and the anticipation of adverse events (Lent, 2013). Botha (2014) posits that adult learners with low levels of self-directedness may lack important psycho-social behavioural requirements such as resiliency and self-efficacy. Coetzee (2014) found that graduate attributes such as a continuous learning orientation, goal-directed behaviour and enterprising skills relate to increased academic self-directedness (e.g. success orientation in an ODL environment, learning resource utilisation, engaged academic activity and motivation).

\section{Employability attributes}

The employability attributes framework of Bezuidenhout (2011) is of relevance to the present research. Bezuidenhout (2011, p. 78) views employability as a psycho-social construct representing a combination of attributes (dispositions, values, attitudes and skills) that promote proactive adaptability in changing environments. Employability attributes are seen to enhance an individual's suitability for employment and increase the likelihood of the person obtaining career success. This view of Bezuidenhout (2011) is in line with other scholars who also describe employability as a multi-faceted concept, comprising certain individual characteristics such as competencies and personality attributes (Fugate et al., 2004; Garnett, 2013; Poropat, 2011; Van der Heijde \& Van der Heijden, 2006). Clark and Zukas (2013) posit that employability is an integral part of an individual's personality and value system, and hence may profoundly affect behaviour. As a result, specific behaviours may always be displayed in particular circumstances. Employability dispositions therefore flow from specific experiences and are also confirmed by other experiences (Clark \& Zukas, 2013). In the current economic and employment climate in South Africa it is imperative upon tertiary education institutions to actively cultivate and vigilantly nurture the employability attributes of their graduates (Coetzee, 2012).

The employability attributes framework of Bezuidenhout (2011) differentiates between eight attributes. These are career self-management, cultural competence, self-efficacy, career resilience, sociability, entrepreneurial orientation, proactivity and emotional literacy (Bezuidenhout, 2011; Botha, 2014; Coetzee, 2012). As shown in Figure 2, Botha (2014) clusters 
these attributes in three psycho-social behavioural dimensions, namely career, intrapersonal and interpersonal.

<Insert figure 2 approximately here>

The intrapersonal dimension involves employability attributes (proactivity, self-efficacy and emotional literacy) that are vital for continued success in the work environment and continued personal growth. Proactivity is being actively involved in career planning and management. Self-efficacy is a personal belief in one's ability to face challenges, be successful and achieve personal goals. Emotional literacy is the capacity to manage and appropriately adapt personal emotions and read the emotions of others (Bezuidenhout, 2011; Coetzee, 2012).

The interpersonal dimension encompasses attributes (sociability and cultural competence) that are essential in the employment milieu and generally in the various social situations people encounter in the pursuit of their careers. Sociability is the ability to grow and successfully utilise social and career networks to enhance career progression. Cultural competence is the ability to adapt easily and appropriately to various cultural situations (Bezuidenhout, 2011; Coetzee, 2012).

The career dimension is associated with particular behaviours (career self-management, career resilience and entrepreneurial orientation) that ensure career success (Botha, 2014). Career self-management is the ability to guarantee sustained employability through the development of a continuous learning orientation and autonomous career planning and management behaviours. Career resilience is the individual capacity to be comfortable with organisational fluctuations because of personal agility and enjoyment of work-related change. An entrepreneurial orientation includes seeing the potential opportunities in risks, accepting uncertainty, being innovative, creative, and autonomously driving career progression (Bezuidenhout, 2011; Coetzee, 2012).

Employability has been associated with self-regulation, the ability to flexibly apply as many different resources and skills as necessary to achieve a goal (Porath \& Bateman, 2006; Van der Heijde, 2014). In this regard, the research literature indicates both self-directedness and employability attributes as important aspects of self-regulation. In line with the reasoning of Van der Heijde (2014) about the notion of self-regulation, self-directedness and employability 
attributes point to a results orientation and manageable behaviours aimed at increasing control over one's career. The two constructs further relate to themes such as autonomy, proactive agency, self-efficacy and lifelong learning (Botha, 2014). Research on employability indicates that employable people focus on the future, are autonomous in their career and are lifelong learners (Bezuidenhout, 2011; Botha, 2014; Clark \& Zukas, 2013; Jackson, 2013). Converse, Pathak, DePaul-Haddock, Gotlib, and Merdebone (2012) suggest positive associations between proactive agency (self-directedness) and educational attainment and continuous learning and development.

\section{Goals of the study}

Based on a review of the literature, it is expected that adult learners' sense of self-directedness will positively affect their self-perceived confidence in their employability attributes. A strong sense of self-directedness will predict positive perceptions about one's employability attributes. The specific research questions that followed from the expected relationship between selfdirectedness and employability attributes were:

1: Does self-directedness significantly and positively relate to employability attributes?

2: Does adult learners' self-directedness significantly predict their perceptions about their employability attributes?

\section{Method}

\section{Participants}

A stratified proportional random sample of $N=1102$ undergraduate adult learners at a South African ODL higher education institution participated in the study. The participants were enrolled in further studies in the economic and management sciences field. The sample consisted of $92 \%$ black students. In terms of age, the sample was represented by participants between 18 and 40 years ( $88 \%$ - early career stage). The sample was further represented by $63 \%$ females and $57 \%$ employed people.

\section{Measuring instruments}


Two measuring scales were used to achieve the objective of the study, namely the Adult Learner Self-directedness Scale (ALSDS) developed by Botha (2014) and the Employability Attributes Scale (EAS) developed by Bezuidenhout and Coetzee (2010).

The ALSDS (Botha, 2014) is a self-report measure consisting of four sub-scales and 35 items, measuring the following attributes and behaviours: strategic utilisation of officially provided resources (five items: e.g. "How do you use the feedback tutorial letters in your studies?"); engaged academic activity (five items: e.g. "How much time do you allow yourself to prepare for the examination?"); success orientation for ODL (11 items: e.g. "How confident are you that you possess the skills to cope in an ODL environment?"); and academically motivated behaviour (14 items: e.g. "What do you do when you struggle to understand the work?"). The ALSDS uses a five-point Likert-type behaviourally-anchored format to measure respondents' responses to each of the items (e.g. 1 = "I am not sure that I will be able to solve problems I encounter in my learning"; 5 = "I am certain that I will be able to solve problems I encounter in my learning"). An exploratory factor analysis by Botha (2014) provides evidence of the internal consistency, reliability and construct validity of the ALSDS. Acceptable internal consistency reliability coefficients (Cronbach's alpha) ranging between 0.60 (strategic utilisation of officially provided resources and engaged academic activity) and 0.77 (success orientation for ODL) were obtained for the present study. The overall scale obtained a Cronbach alpha coefficient of 0.91.

The EAS (Bezuidenhout \& Coetzee, 2010) measures respondents' responses on a sixpoint Likert-type scale ( 1 = never; 6 = always) and consists of 56 items in total: career selfmanagement - 11 items (e.g. 'I know what I must do to make a success of my career'); career resilience - six items (e.g. 'I anticipate and take advantage of changes in my career environment'); entrepreneurial orientation - seven items (e.g. 'I continuously look into new business opportunities'); proactivity - seven items (e.g.' I spend a lot of time enhancing my knowledge and skills to benefit my career'); self-efficacy - six items (e.g. 'When I achieve something, it is because of my own effort'); emotional literacy - seven items (e.g. 'I can easily understand why I feel a certain way'); sociability - seven items (e.g. 'I can use my networks to find new job opportunities'); and cultural competence - five items (e.g. 'I can easily initiate and maintain relationships with people from different cultures'). The EAS has evidenced good 
psychometric validity and reliability in other South African multi-cultural samples (Ndzube, 2013; Potgieter, 2012). High internal consistency reliability coefficients (Cronbach's alpha) ranging between 0.81 (self-efficacy and career resilience) and 0.93 (career self-management) were obtained for the study. The overall scale obtained a Cronbach alpha coefficient of 0.98 .

\section{Research procedure}

Ethical clearance and permission to conduct the study were obtained from the management and research ethics committee of the ODL higher education institution that participated in the study. Questionnaires were mailed to a stratified proportional random sample $(N=4850)$ of students enrolled for studies in the College of Economic and Management Sciences. The sample was stratified by module, qualification, department and school. The survey yielded $n=1102$ useable questionnaires (response rate $=23 \%$ ). Each questionnaire included a covering letter to obtain informed consent from the participants to use their responses for research purposes only. The covering letter explained the purpose of the research, procedure, potential benefits, confidentiality, anonymity, voluntary participation and withdrawal. Participants were requested to complete the questionnaires and return them by mail to the researchers using an enclosed return envelope.

\section{Statistical analysis}

The data were analysed using IBM SPSS (2012) and IBM SPSS Amos (2012). Descriptive statistics, correlational and inferential statistics were used for the purposes of the study. Structural equation modeling (SEM) was performed to assess the overall relationship between the variables associated with the self-directedness construct and the variables associated with the employability attributes construct, and whether self-directedness significantly predicts employability attributes. The SEM goodness-of-fit statistics were evaluated by using the following absolute goodness-of-fit indices: the chi-square test (CMIN), the Root Mean Square Error of Approximation (RMSEA) and the Standardised Root Mean Square Residual (SRMR). The following relative goodness-of-fit indices were used to evaluate the model fit: the Comparative Fit Index (CFI) and the Tucker-Lewis Index (TLI). In line with guidelines provided by Garson (2009), we assumed that an adequate fit of the structural model to the measurement data existed when we obtained a CMIN/df between 1 and 5, CFI and 
TLI values of 0.90 or higher, a RMSEA of 0.08 or lower and a SRMR of 0.05 or lower.

\section{Results}

\section{Descriptive statistics}

Table 1 shows that the participants scored the highest on the ALSDS strategic utilisation of officially provided resources variable $($ Mean $=3.96 ; \mathrm{SD}=0.69)$ and the lowest on the engaged academic activity variable (Mean $=2.68 ; \mathrm{SD}=0.65$ ). In terms of the EAS, the participants scored the highest on career self-management (Mean $=4.80 ; \mathrm{SD}=0.82$ ) and the lowest on sociability $($ Mean $=4.23 ; \mathrm{SD}=0.92)$.

\section{Correlations}

The correlation analysis related to research question 1: Does self-directedness significantly and positively relate to employability attributes?

The correlations between the ALSD and EAS variables ranged between $r \geq 0.07$ (small practical effect) and $r \leq 0.29$ (small practical effect) at $p<0.001$, suggesting significant positive associations between the self-directedness and employability attributes variables. The highest correlations were observed between success orientation to an ODL environment and career selfmanagement $(r=0.29 ; p \leq 0.001)$ and proactivity $(r=0.28 ; p \leq 0.001)$.

<Insert Table 1 approximately here>

\section{Structural equation modelling}

The structural equation modelling analysis related to research question 2: Does adult learners' self-directedness significantly predict their perceptions about their employability attributes?

As shown in Figure 3, the structural equation modelling analysis showed that the data for the ALSD and EAS variables fitted the baseline measurement model well. The fit indices were $\mathrm{CMIN}=275.17(\mathrm{CMIN} / \mathrm{df}=5.19 ; p<0.001) ; \mathrm{RMSEA}=0.065, \mathrm{SRMR}=0.034, \mathrm{CFI}=0.97$ and TLI $=0.96$ (good fit), which is in line with the established joint fit criteria guidelines. The standardised regression weights $(p<0.001)$ for the self-directedness construct ranged between 0.36 (academically motivated behaviour) and 0.73 (success orientation to ODL), showing that 
success orientation for ODL contributed the most to explaining the variance in the selfdirectedness construct. The standardised regression weights $(p<0.001)$ for the employability attributes construct ranged between 0.66 (cultural competence) and 0.91 (proactivity). The results show that proactivity and career self-management (0.86) contributed the most to explaining the variance in the employability attributes construct.

<Insert figure 3 approximately here>

The goodness-of-fit statistics further indicated self-directedness as a significant predictor of employability attributes $(0.42 ; p<0.001)$. The squared multiple correlations data revealed that the model explained $18 \%\left(R^{2}=0.18\right.$; moderate practical effect; $\left.p<0.01\right)$ of the variance in the employability attributes construct.

\section{Discussion}

The study investigated the relationship between adult learners' self-directedness and their employability attributes within an ODL setting. Overall, the results suggest that the participants' self-directedness related positively to and significantly predicted their self-perceived confidence in their employability attributes. These findings suggest that adult learners who pursue further studies in an ODL context and who develop their self-directedness might as a consequence cultivate the required employability attributes to ensure their career success. More specifically, the participants who had a strong sense of self-directedness and especially a success orientation toward studying in an ODL environment seemed to have more confidence in their employability attributes and felt especially positive about their proactivity and career self-management attributes.

A success orientation for ODL is associated with the adult learners' sense of autonomy, intrinsic motivation, learner independence and personal self-sufficiency (Botha, 2014; Garrison, 1997; Silen \& Uhlin, 2008). These attributes could offer an explanation for the positive link with the participants' confidence about their career self-management, which relates to aspects such as identifying and understanding one's values, career goals and intrinsic motivation (Quigley \& Tymon, 2006). Bezuidenhout's (2011) view that career self-management involves positive 
orientations and proactivity in building career skills and improving one's employability could further explain the positive association with a success orientation for mastering one's studies in the ODL setting.

The findings further appear to corroborate research indicating that proactive individuals have high levels of agency (self-directedness) and are more likely to engage in self-enhancing behaviours such as pursuing further education in order to advance their careers (Seibert, Crant, \& Kraimer, 1999) and developing new skills (Fuller \& Marler, 2009). Obschonka, Silbereisen, and Wasilewski (2012) posit in this regard that staying active, being open to the new, and engaging in learning activities may help to maintain or improve personal autonomy and self-determination. Career self-management is associated with self-regulative behaviours aimed at increasing perceived control over one's career (Van der Heijde, 2014). Research by Converse et al. (2012) indicates a relationship between proactive agency (self-directedness) and educational attainment. Research by Elliot and Thrash (2002) further suggests that performance proving and learning orientations that focus on the possibility of success, are both positively related to performance and achievement.

\section{Implications of the study}

This research study provided insight into the self-directedness of adult learners in an ODL setting and the significant and positive relationship between their self-directedness and employability attributes. Knowles (1984) believes that adult learners progressively develop high levels of selfdirectedness as they progress through their studies. Billet (2010) emphasises in this regard the importance of a learning environment that cultivates self-directedness in adult learners. The results of our study indicate that the self-directedness of adult learners in ODL settings may be facilitated by the cultivation of a strong sense of confidence in the ability to successfully master one's studies. Learners' beliefs in their efficacy to regulate their own learning and to master academic activities have been found to determine their aspirations, level of motivation, academic accomplishments and employability satisfaction (Coetzee \& Oosthuizen, 2012). 


\section{Limitations of the study and suggestions for future research}

The following limitations pertaining to the present study must be noted. First, the interpretation of the findings is limited by the cross-sectional nature of the data and the correlational design. Only the magnitude and direction of associations between the self-directedness and employability attributes variables were assessed, and no interpretations can be made regarding the causality of the associations. Longitudinal studies are recommended in order to assess probable antecedents of self-directedness and employability attributes. Second, the potential risk of common method bias should be considered because of the self-report methodology that was used. However, acceptable internal consistency reliabilities were reported for the two measuring instruments. Third, although the sample size was relatively large, the findings cannot be generalised to the total population because of the low response rate and sampling strategy used. Future research initiatives should consider replicating the study for a more representative sample, especially in terms of race, age, gender and employment status. A need exists for further research on adult learner self-directedness in the South African context in various formal, nonformal and informal milieus (Botha, 2014). Further research and possibly longitudinal studies in various learning settings could also provide information on the way in which the selfdirectedness and employability attributes of adult learners change over time as their career selfconcepts and self-efficacy evolve.

\section{Conclusion}

Adult learners' sense of self-directedness affects their perceptions of their employability attributes. In particular, developing confidence in one's ability to successfully master one's studies in an ODL environment may strengthen the adult learner's sense of self-directedness, which in turn may lead to positive perceptions about one's employability attributes and especially one's proactivity, career self-management and career resilience. 


\section{References}

Bezuidenhout, M. (2011). The development and evaluation of a measure of graduate employability in the context of the new world of work (Unpublished master's dissertation). University of Pretoria, South Africa.

Bezuidenhout, M., \& Coetzee, M. (2010). Preliminary exploratory factor analysis: student employability scale. (Unpublished research report). Department of Industrial and Organisational Psychology, University of South Africa, Pretoria.

Billet, S. (2010). Lifelong learning and self: work, subjectivity and learning. Studies in Continuing Education, 32(1), 1-16.

Botha, J. (2012). Graduateness, self-directedness and employability. In M. Coetzee, J. Botha, N. Eccles, N. Holtzhausen \& H. Nienaber (Eds.), Developing student graduateness and employability: issues, provocations, theory and practical guidelines ( $\mathrm{pp}$. 385-402). Randburg: Knowres.

Botha, J. (2014). The relationship between adult learner self-directedness and employability attributes - an ODL perspective (Unpublished master's dissertation). University of South Africa, Pretoria.

Clark, M., \& Zukas, M. (2013). A Bourdieusian approach to understanding employability: becoming a 'fish in water'. Journal of Vocational Education \& Training, 65(2), 208219.

Coetzee, M. (2012). A framework for developing student graduateness and employability in the economic and management sciences at the University of South Africa. In M. Coetzee, J. Botha, N. Eccles, N. Holtzhausen, \& H. Nienaber (Eds.), Developing student graduateness and employability: issues, provocations, theory and practical guidelines (pp. 119-152). Randburg: Knowres.

Coetzee, M. (2014). Exploring the mediating role of graduate attributes in relation to academic self-directedness in ODL. Higher Education Research \& Development, 33(6). 1085 1098. DOI: http://dx.doi.org/10.1080/07294360.2014.911260 
Coetzee, M., \& Beukes, C. (2010). Employability, emotional intelligence and career preparation support satisfaction among adolescents in the school-to-work transition phase. Journal of Psychology in Africa, 20(3), 439-446.

Coetzee, M., \& Botha, J. (2013). Undergraduate students' self-directedness in relation to their examination preparation styles in Open Distance Learning. Progressio, 35(2), 34-57.

Coetzee, M., \& Oosthuizen, R. M. (2012). Students' sense of coherence, study engagement and self-efficacy in relation to their study and employability satisfaction. Journal of Psychology in Africa, 22(3), 315-322.

Converse, P. D., Pathak, J., DePaul-Haddock, A. M., Gotlib, T., \& Merdebone, M. (2012). Controlling your environment and yourself: implications for career success. Journal of Vocational Behavior, 80, 148-158.

De Ture, M. (2004). Cognitive styles and self-efficacy: predicting student success in online distance education. The American Journal of Distance Education, 18(1), 21-38.

Elliot, A. J., \& Thrash, T. M. (2002). Approach-avoidance motivation in personality: approach and avoidance temperaments and goals. Journal of Personality and Social Psychology, $82,804-818$.

Faber, K., López, V., \& Prescher, T. (2012). 'i-learn': developing a new approach in higher education for lifelong learning. European Journal of Higher Education, August, 2(2/3), $218-233$.

Fugate, M., Kinicki, A., \& Ashforth, B. (2004). Employability: a psycho-social construct, its dimensions and applications. Journal of Vocational Behavior, 65, 14-38.

Fuller, B., \& Marler, L. E. (2009). Change driven by nature: a meta-analytic review of the proactive personality literature. Journal of Vocational Behavior, 75, 329-345.

Garnett, J. (2013). Musician and teacher: employability and identity. Music Education Research, 15(1), 1-18.

Garrison, D. R. (1997). Self-directed learning: toward a comprehensive model. Adult Education Quarterly, 48(1), 18-33.

Garson, G. D. (2009). Structural equation modeling. Retrieved from: http://www2.uta.edu/sswmindel/S6367/SEM/Principles\%20of\%20SEM.pdf

IBM SPSS Amos. (2012). IBM Statistical Package for Social Sciences Amos 21.0, Version 4. Meadville, PA: Amos Development Corporation. 
IBM SPSS. (2012). IBM SPSS Statistics for Windows, Version 21.0. Armonk, NY: IBM Corporation.

Jackson, D. (2013). Student perceptions of the importance of employability skill provision in business undergraduate programmes. Journal of Education \& Business, 88(5), 271-279.

Klein-Collins, R. (2011). Strategies for becoming adult-learning-focused institutions. $A A C \& U$, Winter, 4-7.

Knowles, M. S. (1984). Andragogy in action. California: Jossey-Bass.

Ladell-Thomas, J. (2012). Do-it-yourself-information literacy: Self-directed learning at a distance. Journal of Library \& Information Services in Distance Learning, 6(3-4), 376386.

Lai, C., Gardner, D., \& Law, E. (2013). New to facilitating self-directed learning - the changing perceptions of teachers. Innovation in Language Learning and Teaching, 7(3), 281-294.

Lent, R.W. (2013). Career life-preparedness: revisiting career planning and adjustments in the new workplace. The Career Development Quarterly, 6(11), 2-14.

Louw, W. (2014). Designing learning experiences to prepare lifelong learners for the complexities of the workplace. In M. Coetzee (ed.), Psycho-social career metacapacities: dynamics of contemporary career development (pp. 307-320). Dordrecht, The Netherlands: Springer International.

Morrison, A. (2013). A class act? Lecturers' views on undergraduates' employability. British Journal of Sociology of Education, 31(6), 719-735.

Nazar, G., \& Van der Heijden, B. I. J. M. (2012). Career identity and its impact upon selfperceived employability among Chilean male middle-aged managers. Human Resource Development International, 15(2), 141-156.

Ndzube, F. (2013). The relationshp between career anchors and employability (Unpublished Master's dissertation). University of South Africa, Pretoria.

Nel, H., \& Neale-Shuttle, M. (2013). Examining the evidence: graduate employability at NMMU. South African Journal of Higher Education, 27(2), 437-453.

Obschonka, M., Silbereisen, R. K., \& Wasilewski, J. (2012). Constellations of new demands concerning careers and jobs: results from a two-country study on social and economic change. Journal of Vocational Behavior, 80, 211-223. 
Porath, C. L., \& Bateman, T. S. (2006). Self-regulation: from goal orientation to job performance. Journal of Applied Psychology, 91, 185-192.

Poropat, A. E. (2011). The role of citizenship performance in academic achievement and graduate employability. Education \& Training, 53(6), 499-514.

Potgieter, I. L. (2012). The development of a career meta-competency model for sustained employability (Unpublished Doctoral thesis). University of South Africa, Pretoria.

Quigley, N. R., \& Tymon, W.G. (2006). Toward an integrated model of intrinsic motivation and career self-management. Career Development International, 11(6), 522-543.

Seibert, S. E., Crant, J. M., \& Kraimer, M. L. (1999). Proactive personality and career success. Journal of Applied Psychology, 84, 416-427.

Silen, C., \& Uhlin, L. (2008). Self-directed learning: a learning issue for students and faculty. Teaching in Higher Education, 13(4), 461-475.

Thijssen, G. L., Van der Heijden, B. I. J. M., \& Rocco, T. S. (2008). Toward the employability link model: current employment transition to future employment perspectives. Human Resource Development Review, 7(2), 165-183.

Van Der Heijde, C. M., \& Van Der Heijden, J. M. (2006). A competence-based and multidimensional operationalization and measurement of employability. Human Resource Management, 45(3), 449-476.

Van der Heijde, C. M. (2014). Employability and self-regulation in contemporary careers. In M. Coetzee (Ed.), Psycho-social career meta-capacities: dynamics of contemporary career development (pp. 7-18). Dordrecht, The Netherlands: Springer International. 


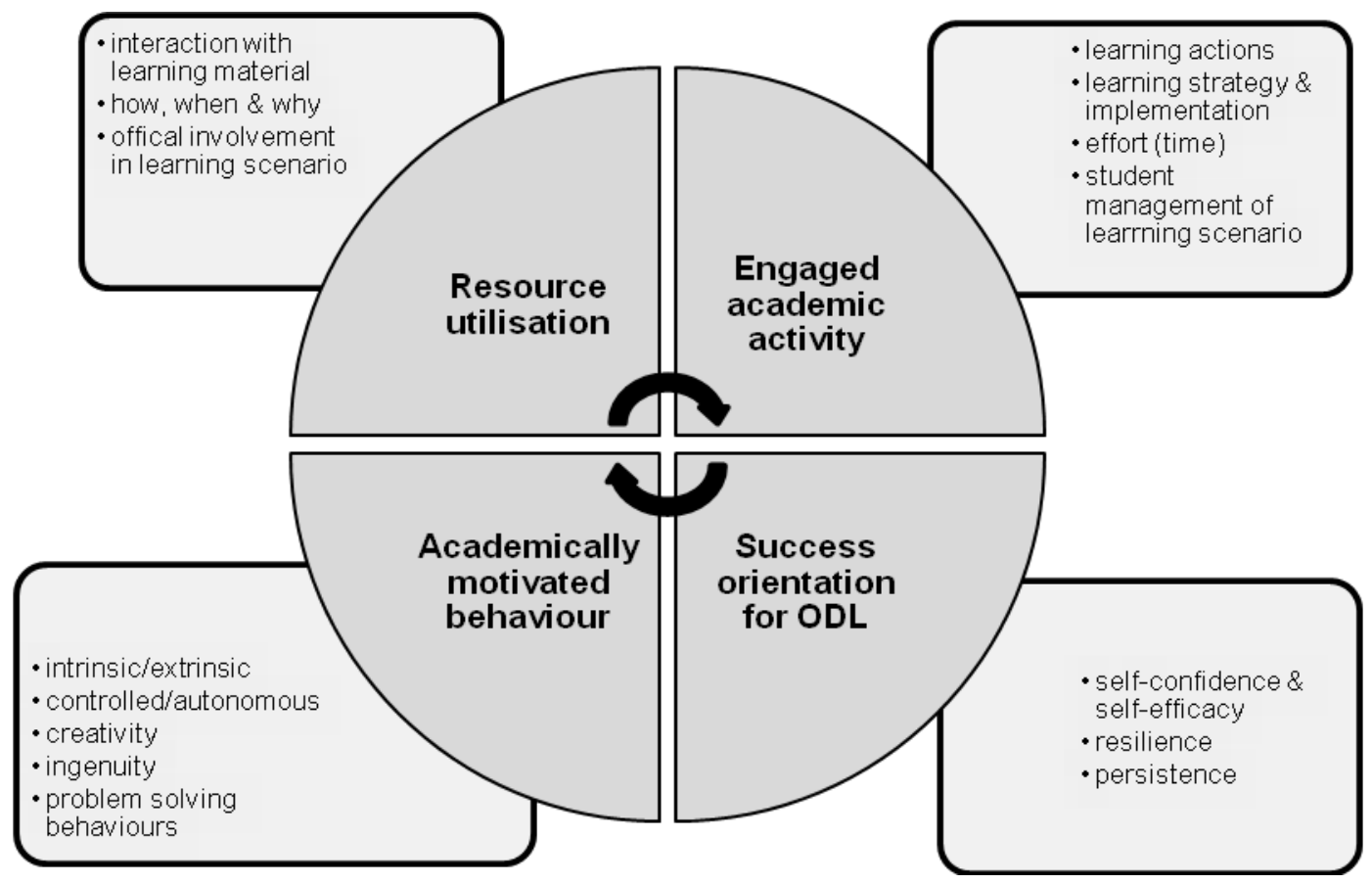

Figure 1. Psycho-social behavioural dimensions of adult learner self-directedness 


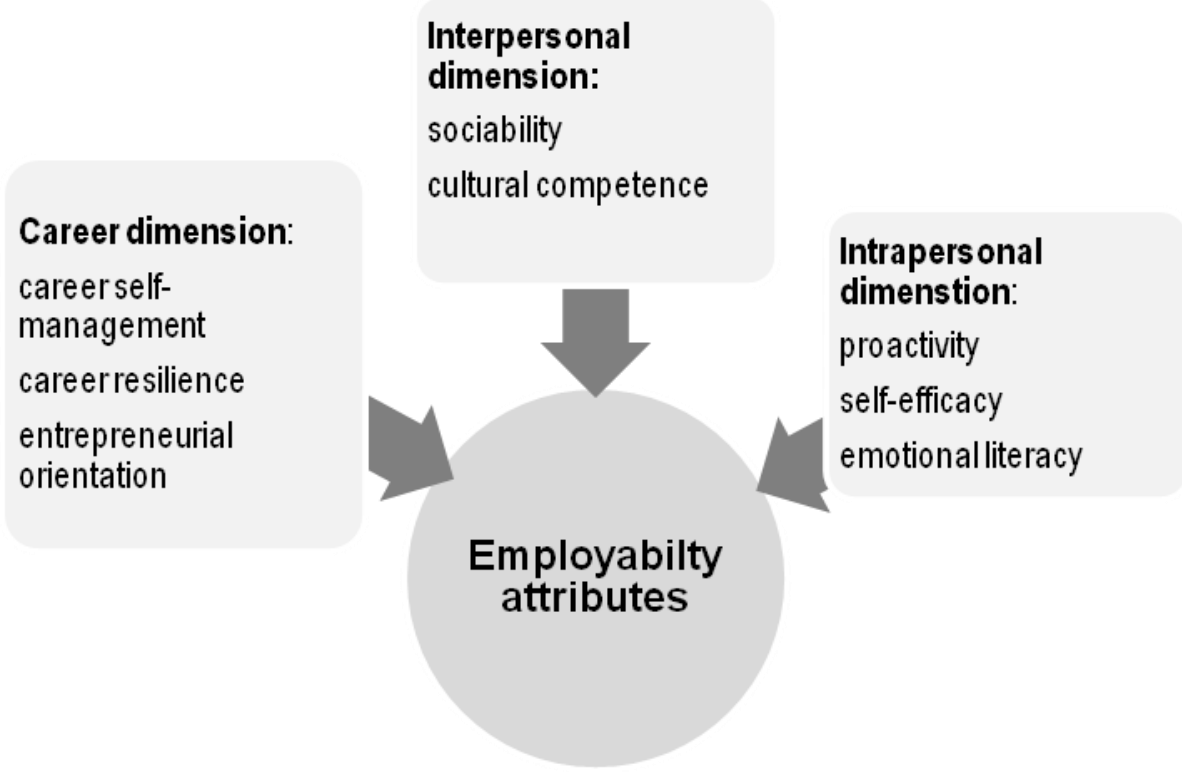

Figure 2. Psycho-social behavioural dimensions of the employability attributes framework 
Table 1. Descriptive statistics and bivariate correlations of the Adult-Learner Self-directedness Scale and Employability Attributes Scale

\begin{tabular}{|c|c|c|c|c|c|c|c|c|c|c|c|c|c|c|c|c|}
\hline & & Mean & $S D$ & $\alpha$ & 1 & 2 & 3 & 4 & 5 & 6 & 7 & 8 & 9 & 10 & 11 & 12 \\
\hline 1 & $\begin{array}{l}\text { Strategic } \\
\text { utilisation of } \\
\text { officially } \\
\text { provided } \\
\text { resources }\end{array}$ & 3.96 & 0.69 & 0.60 & - & & & & & & & & & & & \\
\hline 2 & $\begin{array}{l}\text { Success } \\
\text { orientation to } \\
\text { open distance } \\
\text { learning }\end{array}$ & 3.75 & 0.63 & 0.60 & $0.41 * * *$ & - & & & & & & & & & & \\
\hline 3 & $\begin{array}{l}\text { Engaged } \\
\text { academic } \\
\text { activity }\end{array}$ & 2.68 & 0.65 & 0.77 & $0.28 * * *$ & $0.26 * * *$ & - & & & & & & & & & \\
\hline 4 & $\begin{array}{l}\text { Academically } \\
\text { motivated } \\
\text { behaviour }\end{array}$ & 3.63 & 0.49 & 0.71 & $0.17 * * *$ & $0.29 * * *$ & $0.09 * * *$ & - & & & & & & & & \\
\hline 5 & $\begin{array}{l}\text { Career self- } \\
\text { management }\end{array}$ & 4.80 & 0.82 & 0.93 & $0.23 * * *$ & $0.29 * * *$ & $0.16^{* * *}$ & $0.25 * * *$ & - & & & & & & & \\
\hline 6 & $\begin{array}{l}\text { Cultural } \\
\text { competence }\end{array}$ & 4.38 & 1.06 & 0.93 & $0.09 * * *$ & $0.16^{* * *}$ & $0.07 * * *$ & $0.13 * * *$ & $0.55 * * *$ & - & & & & & & \\
\hline 7 & Self-efficacy & 4.81 & 0.79 & 0.81 & $0.14 * * *$ & $0.19 * * *$ & $0.12 * * *$ & $0.14 * * *$ & $0.69 * * *$ & $0.47 * * *$ & - & & & & & \\
\hline 8 & $\begin{array}{l}\text { Career } \\
\text { resilience }\end{array}$ & 4.46 & 0.87 & 0.81 & $0.19 * * *$ & $0.23 * * *$ & $0.11 * * *$ & $0.18 * * *$ & $0.73 * * *$ & $0.56 * * *$ & $0.65 * * *$ & - & & & & \\
\hline 9 & Sociability & 4.27 & 0.92 & 0.82 & $0.18 * * *$ & $0.24 * * *$ & $0.10 * * *$ & $0.20 * * *$ & $0.70 * * *$ & $0.65 * * *$ & $0.60 * * *$ & $0.74 * * *$ & - & & & \\
\hline 10 & $\begin{array}{l}\text { Entrepreneurial } \\
\text { orientation }\end{array}$ & 4.69 & 0.77 & 0.90 & $0.19 * * *$ & $0.24 * * *$ & $0.15 * * *$ & $0.16 * * *$ & $0.70 * * *$ & $0.52 * * *$ & $0.72 * * *$ & $0.69 * * *$ & $0.66 * * *$ & - & & \\
\hline 11 & Proactivity & 4.65 & 0.86 & 0.82 & $0.21 * * *$ & $0.28 * * *$ & $0.15^{* * *}$ & $0.22 * * *$ & $0.81 * * *$ & $0.58 * * *$ & $0.70^{* * *}$ & $0.79 * * *$ & $0.76^{* * *} *$ & $0.76^{* * *}$ & - & \\
\hline 12 & $\begin{array}{l}\text { Emotional } \\
\text { literacy }\end{array}$ & 4.55 & 0.88 & 0.85 & $0.16 * * *$ & $0.22 * * *$ & $0.10 * * *$ & $0.12 * * *$ & $0.62 * * *$ & $0.56 * * *$ & $0.61 * * *$ & $0.62 * * *$ & $0.60 * * *$ & $0.63 * * *$ & $0.66 * * *$ & - \\
\hline
\end{tabular}

Notes: $N=1102$. .*** $p \leq 0.001-$ statistically significant. 


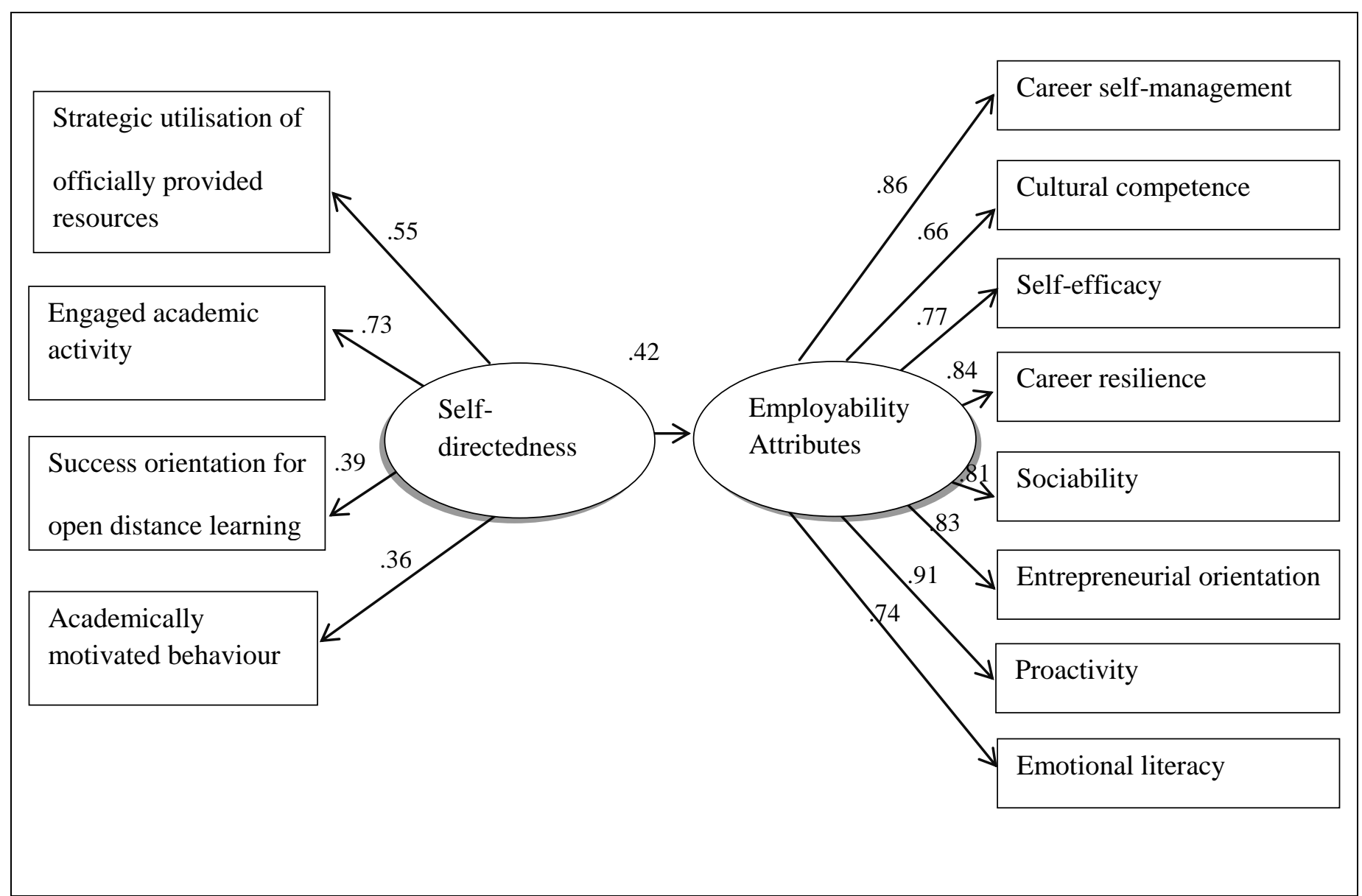

Figure 3. Data fit between the self-directedness and employability attributes variables.

Notes: Entries represent standardised regression weights. Structural pathways are significant at the ***p< 0.01 level. 